\title{
Steroidogenic responses of pig corpora lutea to insulin-like growth factor I (IGF-I) throughout the oestrous cycle
}

\author{
E. A. Miller, Z. Ge, V. Hedgpeth and J. E. Gadsby \\ Department of Molecular Biomedical Sciences, College of Veterinary Medicine, \\ North Carolina State University, Raleigh, NC 27606, USA
}

This study was designed to investigate the roles of insulinlike growth factor I (IGF-I), IGF-type I receptor (IGF-IR) and IGF-binding proteins (IGFBPs) in regulating progesterone secretion by pig corpora lutea during the oestrous cycle, and the signal transduction pathways involved in mediating the steroidogenic actions of IGF-I. Corpora lutea were collected on days 4, 7, 10, 13 and 15 or 16 of the oestrous cycle, enzyme dissociated and the luteal cells were cultured for $24 \mathrm{~h}$ in Medium 199 with IGF-I (0-100 $\left.\mathrm{ng} \mathrm{ml}^{-1}\right)$, long $\mathrm{R}_{3}$-IGF-I $\left(0-100 \mathrm{ng} \mathrm{ml}^{-1}\right)$, anti-IGF-I (Sm 1.2B; 0-10 $\mu \mathrm{g} \mathrm{ml}^{-1}$ ), anti-IGF-IR ( $\alpha$ IR3; 0$2 \mu \mathrm{g} \mathrm{m}^{-1}$ ), or IGF-I signal transduction pathway inhibitors (phosphatidylinositol (PI)-3-kinase: $100 \mathrm{nmol}$ Wortmannin $\mathrm{I}^{-1}$ and $10 \mu \mathrm{mol}$ LY $294002 \mathrm{I}^{-1}$; MAP kinase: $50 \mu \mathrm{mol}$ PD $98059 \mathrm{I}^{-1}$ ) to investigate their effects on IGF-I (100 $\mathrm{n} \mathrm{ml}^{-1}$ ) stimulated progesterone secretion. Pig luteal cells displayed dose-dependent responses to IGF-I and long $R_{3}$-IGF-I on days 4 and 7 of the oestrous cycle, but not on days 10-16. There was no difference in the $\mathrm{ED}_{50}$ or $V_{\max }$ (maximal response) values between IGF-I and long $R_{3}$-IGF-I. Neither anti-IGF-I nor anti-IGF-IR had significant effects on progesterone secretion, at any dose or day. Wortmannin and LY 294002 blocked IGF-I stimulated progesterone secretion, but PD 98059 was without effect. Finally, IGF-I $(6 \mu \mathrm{g})$ infused into the ovary on day 7 in vivo significantly increased progesterone secretion within $45 \mathrm{~min}$ of infusion. The conclusions of this study are: (1) IGF-I has steroidogenic actions only on 'young' (days 4-7) pig corpora lutea; (2) endogenous IGF-I and IGFBP are insufficient to modulate progesterone secretion in vitro; and (3) the steroidogenic actions of IGF-I are mediated via PI-3-kinase.

\section{Introduction}

In most species, corpora lutea can continue to develop for approximately 5 days without pituitary gonadotrophic support before premature luteolysis occurs (Niswender et al., 2000). The pig, however, is unique in that its corpora lutea can continue to develop for 12-14 days without the support of pituitary gonadotrophins (Anderson and Melampy, 1968). Although the exact mechanisms by which this occurs are not well understood, it is hypothesized that a local autocrine or paracrine control pathway involving insulin-like growth factor I (IGF-I) plays an important role in the regulation of corpora lutea development and function during this period (Gadsby et al., 1996; Nicholson et al., 1999; Ge et al., 2000a).

Although the importance of IGF-I to ovarian follicular development has been well established (Hammond et al., 1993; Monget and Bondy, 2000; Guidice, 2001), the role of IGF-I in corpora lutea is less clearly defined. IGF-I mRNA expression has been shown in the corpora lutea of several species including rats (Parmer et al., 1991), humans (Hernandez et al., 1992), sheep (Perks

Email: john_gadsby@ncsu.edu et al., 1995; Juengel et al., 1997), cows (Einspanier et al., 1990; Perks et al., 1999) and pigs (Hammond et al., 1993; Gadsby et al., 1996). IGF-I has been identified in bovine corpora lutea throughout the oestrous cycle by immunocytochemistry (Amselgruber et al., 1994) and is secreted by ovine luteal cells in culture (Wathes et al., 1995). Studies in pig corpora lutea have shown that the steady-state expression of IGF-I mRNA is greater on days 4-10 compared with days $12-16$ of the oestrous cycle, and that IGF-I mRNA is expressed to a greater extent in small compared with large luteal cells (Gadsby et al., 1996). Recently, the expression of IGF-I in early luteal phase pig corpora lutea has been confirmed by demonstrating that luteal concentrations of IGF-I are highest on day 4, compared with the later stages (days 7-16; Z. Ge, W. E. Nicholson, V. Hedgpeth and J. E. Gadsby, unpublished).

The actions of IGF-I are dependent upon a functional type I IGF receptor (IGF-IR; Valentinis and Baserga, 2001). IGF-IR has been detected in the corpora lutea of rats (Parmer et al., 1991; Talavera and Menon, 1991), humans (Hernandez et al., 1992), sheep (Perks et al., 1995) and cows (Sauerwein et al., 1992; Perks et al., 1999). Studies of pig corpora lutea have demonstrated that IGFIR mRNA and protein are expressed and that IGF-IR 
(protein) concentrations are highest on days 4-10, compared with days 13-16 of the oestrous cycle (Ge et al., 2000a). In addition, IGF-IR mRNA and protein are localized predominantly to large (compared with small) luteal cells (Ge et al., 2000a). IGF-I stimulates luteal progesterone secretion in vitro in several species (rats, Parmer et al., 1991; rabbits, Constantino et al., 1991; humans, Apa et al., 1996; sheep, Khan-Dawood et al., 1994; and cows, McArdle and Holtorf, 1989; Sauerwein et al., 1992; Brown and Braden, 2001) including pigs (Huang et al., 1992; Yuan and Lucy, 1996). Furthermore, IGF-I has been shown to stimulate luteal progesterone secretion in vivo in cows (Sauerwein et al., 1992).

The IGF-binding proteins (IGFBPs) are thought to play an important role in modulating the biological actions of the IGFs (Baxter, 2000; Grimberg and Cohen, 2000). IGFBP-2 and -3 are expressed in the corpora lutea of several species (rats, Erickson et al., 1993; primates, Fraser et al., 1998; humans, Fraser et al., 2000; and cows, Brown and Braden, 2001). Expression of mRNA has been demonstrated for IGFBPs-2, $-3,-4$ and -5 in pig corpora lutea (Gadsby et al., 1996), and IGFBP-3 mRNA is expressed predominantly in small luteal cells (Gadsby et al., 1996; Ge et al., 2000b). In addition, the IGFBP-3 protein content of pig corpora lutea is highest on days 4-7, compared with days 10-16 (Z. Ge, W. E. Nicholson, V. Hedgpeth and J. E. Gadsby, unpublished). The role that IGFBPs play in the corpora lutea is not well understood, although as detailed in the discussion, the overwhelming view of the published literature indicates that IGFBPs (in particular IGFBP-3) play an inhibitory role in regulating the action of IGF-I.

In summary, luteal expression of IGF-I, IGF-IR and IGFBP in pigs is greatest during the early luteal phase (days 4-10), supporting the hypothesis that IGF-I plays a critical role in corpora lutea development and function (that is, progesterone secretion) during the period (1214 days) of autonomy from pituitary gonadotrophins. This hypothesis is explored further in the present study by investigating the steroidogenic responses of pig corpora lutea to IGF-I, and the functional roles of IGF-IR and IGFBPs throughout the oestrous cycle, as outlined in the following objectives: (1) to examine the function of the luteal IGF-IR at different stages of the oestrous cycle; (2) to explore the role of endogenous IGF-I; (3) to examine the role of endogenous IGFBPs in modulating luteal IGF-I responses; and (4) to explore the signal transduction pathway mediating the steroidogenic actions of IGF-I.

\section{Materials and Methods}

\section{Materials}

Medium 199 (M199 with Hank's salts and L-glutamine) was purchased from Gibco-Invitrogen Corp. (Grand
Island, NY). Hank's Balanced Salt Solution (HBSS; without calcium and magnesium), Hepes, sodium bicarbonate, hydrocortisone, DNase (type I from bovine pancreas), hyaluronidase (type II from ovine testes), BSA (fraction V), human low density lipoprotein (LDL), penicillin-streptomycin solution, dimethyl sulphoxide (DMSO), Wortmannin, LY 294002 and PD 98059 were obtained from Sigma-Aldrich Chemical Company (St Louis, MO). Gentamycin sulphate (biotech research grade) and sodium citrate were obtained from FisherBiotech (Fair Lawn, NJ). Collagenase (type IV) was purchased from Worthington Biochemical Corp. (Lakewood, NJ). The Coat-a-Count ${ }^{\circledR}$ progesterone radioimmunoassay kits were purchased from Diagnostic Products Corp. (Los Angeles, CA). Long R3-IGF-I was obtained from Diagnostic Systems Laboratories (Webster, TX) and IGF-I was purchased from R \& D Systems (Minneapolis, MN). Anti-human IGF-I (Sm 1.2B clone) was obtained from Upstate Biotechnology (Lake Placid, NY) and anti-IGF-IR ( $\alpha$ IR3 clone) was purchased from Oncogene Research Products (Cambridge, MA).

\section{Lipoprotein preparation}

The LDL fraction from pig plasma was obtained by differential ultracentrifugation, using blood obtained from barrows as described by Richards et al. (1994).

\section{Animals and collection of ovaries}

The experimental protocol involving animal care and use was performed with the approval of the North Carolina State University (NCSU) Institutional Animal Care and Use Committee.

Naturally cycling pubertal gilts (Sus scrofa; Newsham $\times$ Hampshire $\times$ Duroc hybrid; from the NCSU Swine Education and Research Facility) were checked once per day for oestrous behaviour with a mature boar. The first day on which oestrus was observed was considered to be day 0 of the oestrous cycle. On days $4,7,10,13$ and 15 or 16 ( $n=5$ animal per day for all stages except days 15 and 16 , for which $n=4$ ) of the oestrous cycle, animals were ovariectomized (Gadsby et al., 1990). Ovaries or corpora lutea were obtained from animals on day 6 or 7 of the oestrous cycle for the small or large luteal cell cultures and signal-transduction pathway studies.

\section{Dissociation of corpora lutea and cell separation}

Ovaries collected at surgery were immediately placed in sterile Hank's Medium (HBSS containing $20 \mathrm{mmol}$ Hepes $\mathrm{I}^{-1}, 4 \mathrm{mmol}$ sodium bicarbonate $\mathrm{I}^{-1}, 100000 \mathrm{iu}$ penicillin $I^{-1}, 100 \mathrm{mg}$ streptomycin $\mathrm{I}^{-1}$, $50 \mathrm{mg}$ gentamicin $I^{-1}$, and $2 \mathrm{~g} \mathrm{BSAl}^{-1}$ ) and transported to the laboratory on ice. All subsequent procedures, except where noted otherwise, were performed on ice. Corpora 
lutea were dissected from the ovaries, weighed and then diced into small pieces with scalpel blades. The dissected tissue was placed in an Ehrlenmeyer flask with $40 \mathrm{ml}$ of Hank's medium and incubated for $30 \mathrm{~min}$ at $37^{\circ} \mathrm{C}$. Enzymatic dissociation of corpora lutea was then performed as described by Gadsby et al. (1990). The total number of large and small luteal cells was counted using a haemocytometer and the viabilities of small and large cells were monitored by Trypan blue exclusion.

Small and large luteal cells were separated using centrifugal elutriation (Gadsby et al., 1990; Gadsby and Earnest, 1994; Ge et al., 2000a), and were cultured separately.

\section{Culture of luteal cells}

The luteal cell culture procedure was performed as described by Richards et al. (1994). Briefly, the mixed, small or large luteal cell preparations were diluted in M199 containing $22 \mathrm{mmol}^{\mathrm{H}}$ Hepes $\mathrm{I}^{-1}, 4 \mathrm{mmol}$ sodium bicarbonate $\mathrm{I}^{-1}, 100000$ iu penicillin $\mathrm{I}^{-1}, 100 \mathrm{mg}$ strep-

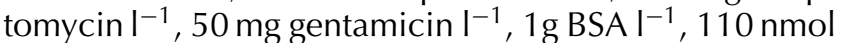
hydrocortisone $\mathrm{I}^{-1}$ and $50 \mathrm{mg}$ (cholesterol) pig LDL ${ }^{-1}$ (M199). Costar 24-well tissue-culture treated polystyrene plates (Corning Inc., Corning, NY) were seeded with 30000 large (large cell preparations), 150000 small (small cell preparations) or 30000 large plus about 100000-250000 small luteal cells (mixed cell preparations; on the basis of a fixed large cell count and a variable number of small cells depending on stage of the oestrous cycle). Various concentrations of the following treatments were added to each well (in $1 \mathrm{ml}$ ): IGF-I $\left(0,0.1,1,10,100 \mathrm{ng} \mathrm{ml}^{-1} ; n=4\right.$ per dose per animal), long $\mathrm{R}_{3}$-IGF-I $\left(0,0.1,1,10,100 \mathrm{ng} \mathrm{ml}^{-1}\right.$; $n=4)$, anti-IGF-I (Sm 1.2B; 0, 0.625, 1.25, 2.5, 5, $\left.10 \mu \mathrm{g} \mathrm{ml}^{-1} ; n=4\right)$ and anti-IGF-IR ( $\alpha$ IR3; 0, 0.1, 0.2, $\left.0.5,1,2 \mu \mathrm{gll}^{-1} ; n=4\right)$. The doses selected for antiIGF-IR were as suggested by Rohlik et al. (1987). In addition, a preliminary experiment showed that antiIGF-IR (using the doses given above) dose-dependently inhibited the stimulatory effects of $10 \mathrm{ng}$ IGF-I ml ${ }^{-1}$, confirming the efficacy of this antibody with pig luteal cells. A range of concentrations was used for anti-IGF-I, encompassing the dose (equivalent to $3.6 \mu \mathrm{g} \mathrm{ml}^{-1}$ ) found to be effective at blocking the action of IGF-I on pig granulosa cells (Mondschein et al., 1989). Each treatment was diluted in the M199 culture medium described above. Plates were centrifuged at $250 \boldsymbol{g}$ for $5 \mathrm{~min}$ at $4^{\circ} \mathrm{C}$ to facilitate attachment of cells to the bottom of the well. The plates were then incubated in a humidified incubator at $37^{\circ} \mathrm{C}$ with $5 \% \mathrm{CO}_{2}$ in air for 20-24 h. After culture, 24-well plates were again gently centrifuged and the spent media collected for progesterone determination by radioimmunoassay. Cells were removed from the culture wells by trypsinization for monitoring the number and viability of cells in some experiments. This study confirmed the findings of Richards et al. (1994) that there are no significant changes in the number or viability of luteal cells over the course of the 20-24h culture period (data not shown).

\section{Inhibitor studies}

The signal transduction pathways mediating the steroidogenic actions of IGF-I were explored using the luteal cell culture system described above. These studies used 50000 (large cell count) mixed luteal cells per well and human LDLs. Preliminary studies found that human LDL (same dose as for pig LDL; $50 \mathrm{mg}_{\text {cholesterol }}{ }^{-1}$ ) was a suitable substitute (for pig LDL) cholesterol source in these cultures (data not shown). These studies utilized the phosphatidylinositol (PI)-3-kinase inhibitors, Wortmannin and LY 294002, and the MAP-kinase inhibitor, PD 98059, at the following doses: $100 \mathrm{nmol}$ Wortmannin $\mathrm{I}^{-1}$; $10 \mu \mathrm{mol}$ LY $294002 \mathrm{I}^{-1} ; 50 \mu \mathrm{mol}$ PD 98059 $\mathrm{I}^{-1}$ (Westfall et al., 2000; Chen et al., 2001). Inhibitors were dissolved in DMSO to generate stock solutions and added at the beginning of culture in $\leqslant 0.1 \%(\mathrm{v} / \mathrm{v})$ culture medium. In preliminary experiments $0.1 \%$ DMSO had no effect on control or IGF-I-treated cultures.

\section{Ovarian infusion studies, in vivo}

Animals were anaesthetized and maintained at a surgical plane of anaesthesia (Gadsby et al., 1990) on day 7 of the oestrous cycle. The ovaries were exposed via a mid-line ventral laparotomy and a 23-gauge butterfly catheter (3 or 4 inch needle, 6 inch catheter; Abbott Laboratories, Chicago, IL), for blood collection, was inserted into the vasculature located in the ovarian hilus (Oxenreider et al., 1965); a second butterfly catheter for IGF-I or vehicle infusion was inserted adjacent to the first catheter. Both catheters were secured in place with super-glue (Quick Gel; Duro, Hartford, CT) and Dermabond (Ethicon/Johnson and Johnson, Somerville, $\mathrm{NJ}$ ), and flushed with $3.5 \%$ sodium citrate. Blood samples were collected at approximately 5-10 min intervals for approximately $30 \mathrm{~min}$ before infusion. At time 0 , IGF-I (6 $\mu$ g per ovary; $n=3$ animals) or vehicle $(n=2$; sodium citrate) was infused into the ovary in $0.25 \mathrm{ml}$ vehicle over 1-2 min. Blood sampling from the ovarian catheter was continued at 5-15 min intervals for 90$120 \mathrm{~min}$. Blood samples were also collected at regular intervals (as described for ovarian samples) from the ear vein, before and after IGF-I or vehicle infusion. Blood samples were allowed to clot at room temperature, stored overnight at $4{ }^{\circ} \mathrm{C}$ and then centrifuged $(600 \mathrm{~g}$ for $20 \mathrm{~min}$ ) to collect serum. Serum samples were stored at $-20^{\circ} \mathrm{C}$ before assay for progesterone using radioimmunoassay. 
Table 1. Dose-response characteristics of steroidogenic responses of pig luteal cells to insulin-like growth factor I (IGF-I) and long $\mathrm{R}_{3}$-IGF-I

\begin{tabular}{|c|c|c|c|c|}
\hline \multirow{2}{*}{$\begin{array}{l}\text { Day } \\
\text { of } \\
\text { cycle }\end{array}$} & \multicolumn{2}{|c|}{ IGF-I } & \multicolumn{2}{|c|}{ Long $R_{3}-I G F-I$} \\
\hline & $\begin{array}{c}\mathrm{ED}_{50} \\
\left(\mathrm{ng} \mathrm{ml}^{-1}\right)\end{array}$ & $\begin{array}{c}\mathrm{V}_{\max } \\
(\% \text { of control) }\end{array}$ & $\begin{array}{c}\mathrm{ED}_{50} \\
\left(\mathrm{ng} \mathrm{ml}^{-1}\right)\end{array}$ & $\begin{array}{c}\mathrm{V}_{\max } \\
(\% \text { of control) }\end{array}$ \\
\hline 4 & $6.6 \pm 1.6(5)$ & $135 \pm 2.8$ & $7.2 \pm 2.1(4)$ & $132 \pm 7.5$ \\
\hline 7 & $4.1 \pm 2.0$ & $138 \pm 4.4(5)$ & $3.6 \pm 2.8(3)$ & $140 \pm 2.8$ \\
\hline
\end{tabular}

Data are expressed as mean \pm SEM. Numbers in parenthesis $=n$.

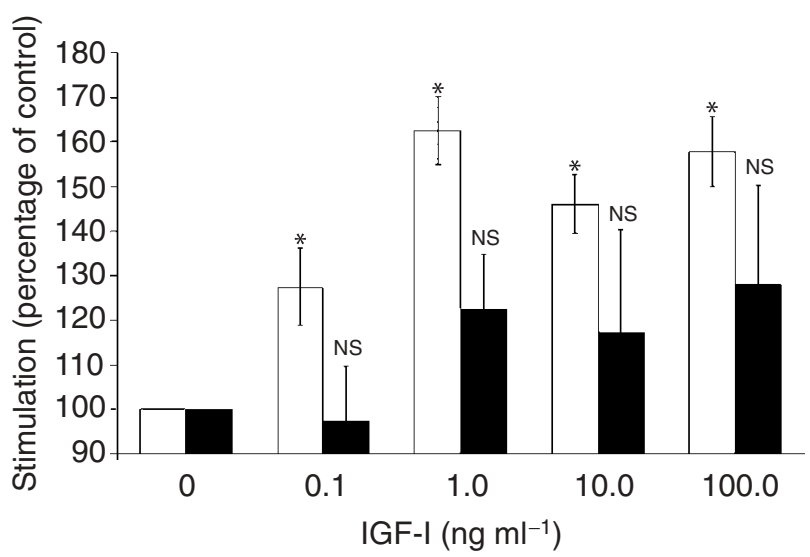

Fig. 1. Effects of insulin-like growth factor I (IGF-I) on progesterone secretion by large $(\square)$ and small ( $\square$ ) pig luteal cells. Data are presented as the stimulation of progesterone accumulation into the culture medium, expressed as a percentage, relative to controls (that is, no IGF-I $=100 \%$ ). Data are presented as mean \pm SEM for three separate experiments (luteal cells from three individual pigs at day 7$)$. ${ }^{*}$ Significant increase above controls $(P<0.05$; ANOVA); NS, not significant.

\section{Progesterone radioimmunoassay}

Media were collected from luteal cell cultures, centrifuged ( $600 \mathrm{~g}$ for $20 \mathrm{~min}$ at $4^{\circ} \mathrm{C}$ ) and immediately stored at $-20^{\circ} \mathrm{C}$. Progesterone concentrations (serum and media) were measured using the Coat-a-Count ${ }^{\circledR}$ radioimmunoassay kits as described and validated (serum, Gadsby et al., 1991; media, Richards et al., 1994).

\section{Statistical analysis}

Data were normalized within each culture (animal) for controls, expressed as a percentage of the control value $(=100 \%)$ and averaged across replicate for each treatment. Data were then averaged for day of oestrous cycle (for each treatment) and examined for treatment effects across days of the oestrous cycle using ANOVA and Fisher's post hoc test (Statview, Abacus Concepts, CA), with $P<0.05$ as the significance level.

\section{Results}

In vitro studies

Responses of isolated large and small luteal cells to IGF-I. When large and small luteal cells (day 7), isolated and separated by elutriation, were cultured separately with $0-100 \mathrm{ng}$ IGF-I mI ${ }^{-1}$, only large cell preparations demonstrated a significant $(P<0.05)$ dose-dependent increase in progesterone secretion (Fig. 1), with a maximum stimulation of about $160 \%$ at $1 \mathrm{ng} \mathrm{ml}^{-1}$. There was no significant stimulation observed with small luteal cells, although numerically they displayed a slight but variable response. All subsequent studies used mixed luteal cell preparations and a fixed number of large luteal cells (that is, 30000 cells per well for most studies), as large luteal cells appeared to be the primary target cell for the steroidogenic actions of IGF-I.

IGF-I and long $R_{3}$-IGF-I dose-response. Dosedependent increases in progesterone secretion in response to IGF-I and long $R_{3}$-IGF-I were observed only on days 4 and 7 (Fig. 2). From the dose-response curves constructed from the data for days 4 and 7, estimates of $\mathrm{ED}_{50}$ value (that is, dose giving $50 \%$ of maximal response) and $V_{\max }$ (maximal response) were obtained (Table 1 ). These data indicate that steroidogenic responses of mixed luteal cells on days 4 and 7 to IGF-I and long $R_{3}$-IGF-I were similar in terms of $\mathrm{ED}_{50}\left(3-7 \mathrm{ng} \mathrm{ml}^{-1}\right)$ and $\mathrm{V}_{\max }$ (132-140\%) values.

Effects of IGF-I and long $R_{3}-I G F-I$ on different days of the oestrous cycle. The effects of IGF-I and long $R_{3}-I G F-I$ on progesterone secretion by pig luteal cells on days 4 and 7 are shown (Fig. 2a,b). IGF-I elicited significant $(P<0.05)$ dose-dependent increases in progesterone secretion at 1,10 and $100 \mathrm{ng} \mathrm{ml}^{-1}$ (in five out of five animals), on both days 4 and 7 , giving maximal responses of $135 \%$ and $142 \%$ (above control; at $100 \mathrm{ng} \mathrm{ml}^{-1}$ ), respectively. Long $\mathrm{R}_{3}$-IGF-I was stimulatory (significantly, in four out of five animals on day 4 , and three out of five animals on day 7; $P<0.05)$ to steroidogenesis only at 10 and $100 \mathrm{ng} \mathrm{ml}^{-1}$, although the maximal responses $(128 \%$, day $4 ; 140 \%$, day 7 ) were not significantly different from that seen with IGF-I. During days 10-16, no significant stimulatory steroidogenic responses to $0.1-100 \mathrm{ng} \mathrm{ml}^{-1}$ of either IGF-I or long $\mathrm{R}_{3}$-IGF-I were observed on days $10,13,15$ or 16 (data not shown).

Effects of anti-IGF-I and anti-IGF-receptor sera on different days of the oestrous cycle. The effects of monoclonal antibodies to IGF-I (Sm 1.2B) and to IGFIR $(\alpha I R 3)$ were examined to investigate the roles of endogenous IGF-I in maintaining basal progesterone secretion by pig luteal cells in culture at different stages of the oestrous cycle. Neither of these antibodies had consistent or significant effects on progesterone secretion 


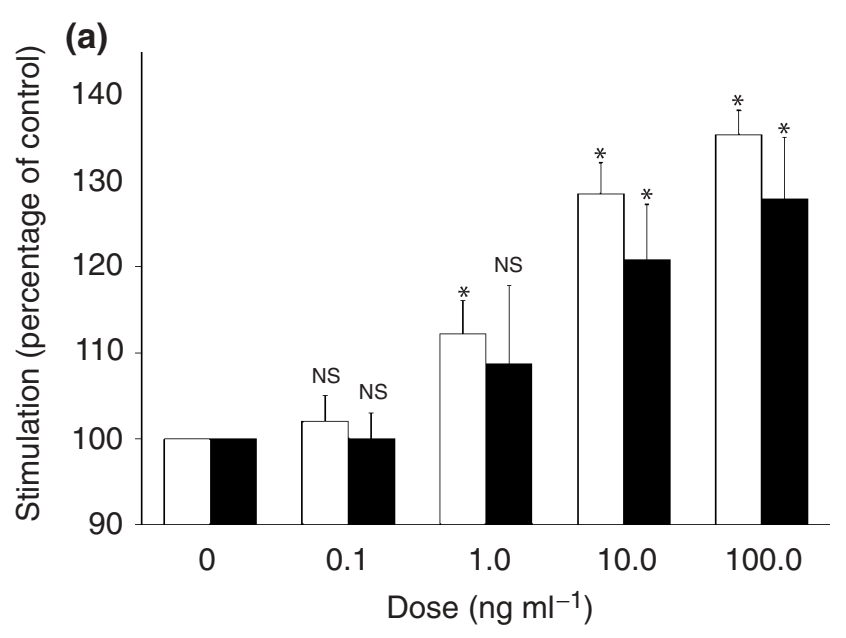

(b)

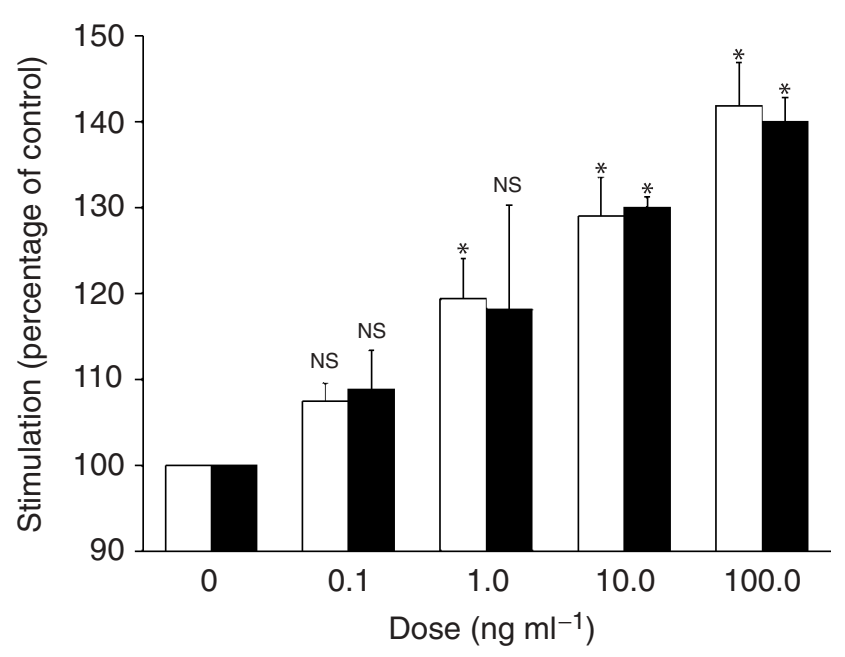

Fig. 2. Effects of insulin-like growth factor I (IGF-I; $\square$ ) and long $\mathrm{R}_{3}$-IGF-I ( $\left.\mathbf{\square}\right)$ on progesterone secretion by mixed pig luteal cells obtained on (a) day 4 and (b) day 7 of the oestrous cycle. Data are presented as the stimulation of progesterone accumulation into the culture medium, expressed as a percentage, relative to controls (that is, no IGF-I $=100 \%$ ). Data are presented as mean \pm SEM for five animals (days 4 and 7 ; IGF-I), and for four (day 4) and three (day 7) animals, respectively (long $\left.\mathrm{R}_{3}-\mathrm{IGF}-\mathrm{I}\right)$. *Significant increase above controls $(P<0.05$; ANOVA); NS, not significant.

at any dose or stage of the oestrous cycle (data not shown).

Effects of PI-3-kinase and MAP-kinase inhibitors on IGF-I stimulated steroidogenesis. The effects of PI-3-kinase and MAP-kinase inhibitors on progesterone secretion are shown (Fig. 3). These data indicate that Wortmannin $(111 \pm 1.5 \%)$ and LY $294002(116 \pm 1.3 \%)$ both significantly $(P<0.05$ versus IGF-I alone) inhibit the stimulatory actions of IGF-I $(130 \pm 4.1 \%)$ on pig luteal cell steroidogenesis. However, PD 98059 (127 $\pm 2.7 \%$ ) was without effect and was not able to significantly

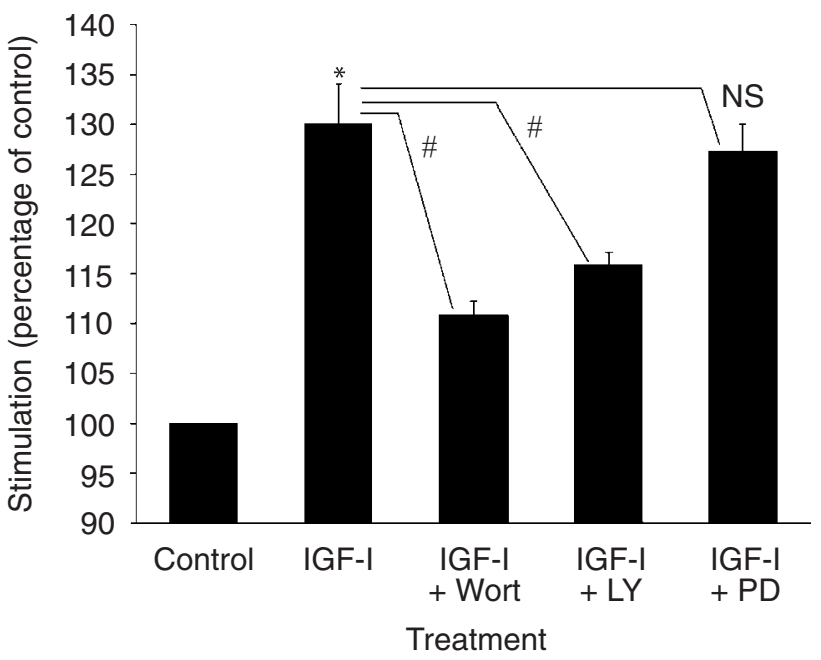

Fig. 3. Effects of inhibitors $\left(100 \mathrm{nmol}\right.$ Wortmannin $\mathrm{I}^{-1}$ (Wort); $10 \mu \mathrm{mol}$ LY $294002 \mathrm{I}^{-1}$ (LY); $50 \mu \mathrm{mol}$ PD $98059 \mathrm{I}^{-1}$ (PD)) on insulin-like growth factor I (IGF-l; $100 \mathrm{ng} \mathrm{ml}^{-1}$ ) stimulated progesterone secretion by mixed pig luteal cells obtained on day 6 or day 7 of the oestrous cycle. Data are presented as the stimulation of progesterone accumulation into the culture medium, expressed as a percentage, relative to their appropriate controls (that is, no-inhibitor, Wort, LY or PD, without IGF-I $=100 \%$ ). Data are presented as mean $\pm \operatorname{SEM}(n=4$ replicates per treatment) for a representative experiment (of four or five separate experiments). *Significant increase above controls $(P<0.05$; ANOVA); \#significant inhibition of the IGF-I response $(P<0.05$; ANOVA; decrease relative to IGF-I treatment); NS, not significant.

(versus IGF-I without inhibitor) inhibit the luteal cell response to IGF-I.

\section{In vivo studies}

Effects of IGF-I infusion in vivo. IGF-I (or vehicle, control) was infused (for 1-2 min) and the progesterone concentrations examined in ovarian and ear vein blood samples collected for $2 \mathrm{~h}$ in experiments designed to examine the steroidogenic responses to IGF-I in vivo. The data indicated that vehicle infusion (control treatment) had no significant effect on progesterone secretion (ovarian blood, Fig. 4; ear vein blood, data not shown). However, it was noted that at 45-120 min, serum progesterone concentrations were significantly reduced compared with pre-infusion concentrations in ovarian blood (Fig. 4). Infusion of IGF-I induced a significant increase $(130 \% ; P<0.05$ versus pre-infusion concentrations) in progesterone concentrations in ovarian blood during the first $45 \mathrm{~min}$ after infusion (Fig. 4). Subsequently, progesterone concentrations returned to pre-infusion concentrations at 45-120 min (Fig. 4). Although progesterone concentrations were increased slightly during the $0-45 \mathrm{~min}$ after IGF-I infusion as measured in ear vein samples, this effect was significant (116\%) only in one animal (data not shown). 


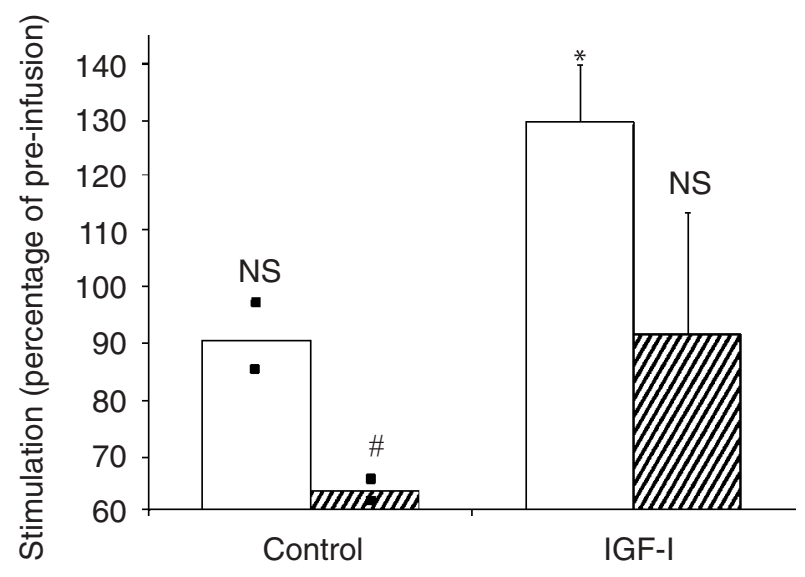

Fig. 4. Steroidogenic response of pig corpora lutea to insulinlike growth factor I (IGF-I) in vivo. IGF-I ( $6 \mu \mathrm{g}$ per ovary) or vehicle (control) was infused into the ovarian vasculature and progesterone concentrations were measured in ovarian blood samples collected every $5-15 \mathrm{~min}$ from about $30 \mathrm{~min}$ before infusion $(-30$ to $0 \mathrm{~min}=$ pre-infusion), up to $120 \mathrm{~min}$ after infusion. Data are presented as the stimulation of progesterone secretion, expressed as a percentage, relative to pre-infusion (that is, -30 to $0 \mathrm{~min}=100 \%$ ) as measured at 0-45 min ( $\square$ ) and 45-120 min ( Data are presented as the mean of two animals (vehicle, control) and the mean \pm SEM of three animals (IGF-I), examined on day 7 of the oestrous cycle. The values for each of the individual control animals are indicated by (ם). *Significant increase above preinfusion values $\left(P<0.05\right.$; ANOVA); ${ }^{*}$ significant decrease below pre-infusion values $(P<0.05 ;$ ANOVA $)$; NS, not significant.

Progesterone concentrations in ear vein blood samples were not significantly changed at $45-120 \mathrm{~min}$ after infusion of IGF-I compared with pre-infusion values (data not shown).

\section{Discussion}

This study was designed to assess the function of IGF-IR and the roles of endogenous IGF-I and IGFBPs on the steroidogenic activity of pig corpora lutea. In addition, the signal transduction pathway involved in mediating the steroidogenic actions of IGF-I on pig luteal cells was examined.

The function of the luteal IGF-IR at different stages of the oestrous cycle was examined by monitoring the capacity of IGF-I agonists to increase progesterone production by luteal cells in culture. As IGF-IR concentrations (protein) in pig corpora lutea are highest at the beginning of the oestrous cycle (days 4-10) and decline thereafter (Ge et al., 2000a), it was anticipated that IGF-I would be more stimulatory to luteal cells on days 4-10 than on subsequent days. Indeed, IGF-I elicited dose-dependent increases in progesterone secretion by luteal cells on days 4 and 7 , but not on days 10-16, partially confirming the expectation that response to IGF-I in vitro would correlate with luteal IGF-IR concentrations. However, the lack of a significant response on day 10 was unexpected, especially as IGF-IR concentrations remain increased on this day (Ge et al., 2000a). Potential explanations for the lack of IGF-I response on day 10 are that the IGF-IR was not functioning optimally or that there were deficiencies in one or more components of the IGF-IIGF-IR signal transduction pathway leading to increased progesterone secretion. Future studies will be directed towards examining these and other possible mechanisms underlying the decline in luteal sensitivity to IGF-I on days $10-16$.

Results from the present study confirm reports showing that IGF-I can stimulate luteal cell steroidogenesis in various species including rats (Parmer et al., 1991), rabbits (Constantino et al., 1991), humans (Apa et al., 1996), cows (McArdle and Holtorf, 1989; Sauerwein et al., 1992) and pigs (Huang et al., 1992; Yuan and Lucy, 1996). However, the present study, which examined IGF-I responsiveness of luteal cells collected at different stages of the oestrous cycle in pigs, successfully (on days 4, 7, 13, 15 or 16) correlated functional (steroidogenic) activity of the luteal IGF-I receptor with IGF-IR concentrations. To the authors' knowledge, this has not been reported previously in pigs or any other species. Thus, these findings represent an important advance in the understanding of the role played by IGF-I in corpora lutea development and function.

In addition, the present study shows that large luteal cells respond to IGF-I with increased progesterone secretion in a dose-dependent manner, whereas steroidogenesis by small luteal cells is not significantly increased by IGF-I. This confirms the findings of Yuan and Lucy (1996) and is also consistent with the observations that IGF-IR mRNA and protein are preferentially expressed in large luteal cells in pigs (Ge et al., 2000a). Thus, these data strongly indicate that IGF-I is an important regulator of steroidogenesis in large luteal cells in pigs, particularly during the early stages (days 4 and 7) of the luteal phase. However, as expression of IGF-IR mRNA and protein in small luteal cells is low (Ge et al., 2000a), and small luteal cells show a tendency for increased steroidogenesis (the present study), these cells cannot be excluded as potential targets for the actions of IGF-I.

Finally, the present study, using an ovarian infusion model system, provides confirmation in vivo of the steroidogenic actions of IGF-I on pig corpora lutea. In addition, the acute (within $45 \mathrm{~min}$ ) nature of the steroidogenic response to IGF-I has been demonstrated. The data are in agreement with studies carried out in bovine corpora lutea using in vivo microdialysis, in which the authors also demonstrated an acute (about $30 \mathrm{~min}$ ) increase in progesterone secretion (Sauerwein et al., 1992). Preliminary studies examined the time course of the action of IGF-I on pig luteal cells in vitro and found that IGF-I has significant stimulatory effects on 
progesterone secretion as early as $4 \mathrm{~h}$ after administration (Z. Ge, V. Hedgpeth and J. E. Gadsby, unpublished), further demonstrating the acute nature of the steroidogenic response to IGF-I.

The second objective of this study was to explore the role of endogenous IGF-I and IGF-IR activity by the use of blocking antibodies in cell cultures. Thus, the study attempted to block endogenous IGF-I via the addition of a monoclonal antibody to IGF-I (Sm 1.2B), which has been shown to block the bioactivity of IGF-I in pig granulosa cell cultures (Mondschein et al., 1989). In addition, an antibody known to block the type-I IGF receptor was used ( $\alpha$ IR3; Rohlik et al., 1987), thus preventing the IGF-I activation pathway. No significant decrease in progesterone secretion by luteal cells cultured with either the IGF-I or IGF-IR antibody, at any dose, or on any day of the oestrous cycle was shown. One possible explanation for these observations is that the endogenous amounts of IGF-I in the luteal cell cultures were insufficient to exert a stimulatory response on steroidogenesis. On the basis of data obtained from other studies (Nicholson et al., 1999; Z. Ge, W. E. Nicholson, V. Hedgpeth and J. E. Gadsby, unpublished) in which the IGF-I protein content of pig corpora lutea was measured (by radioimmunoassay), it is estimated that IGF-I in the luteal cell cultures described here would be about 55 and about 37 pg per well (or per $\mathrm{ml}$ ) on days 4 and 7, respectively; amounts probably too low to activate IGF-IR ( $\mathrm{ED}_{50}$ value $4-7 \mathrm{ng} \mathrm{ml}^{-1}$ ). It is not known how much IGF-I is secreted by pig luteal cells during 20-24 h of culture, but the present study strongly indicates that the concentrations of endogenous plus secreted IGF-I are too low to drive basal steroidogenesis in this cell culture system.

The role of endogenous IGFBPs in the luteal IGF-I response mechanism was examined. The presence of endogenous IGFBPs within pig corpora lutea has been documented by demonstrating the expression of mRNAs for IGFBPs 2-5 (Gadsby et al., 1996), and by showing that the amounts of luteal IGFBP-3 protein in particular are highest on days 4-7 of the oestrous cycle (Ge et al., 1998; Z. Ge, W. E. Nicholson, V. Hedgpeth and J. E. Gadsby, unpublished). Although it is clear that IGFBPs are important in regulating the bioavailability of IGF-I to its receptors, it is still controversial as to whether such actions facilitate or inhibit the action of IGF-I on its receptor (Baxter, 2000; Grimberg and Cohen, 2000). Thus, although there is some evidence indicating that IGFBPs can facilitate the actions of IGF-I on target cells, most of the data on IGFBPs indicates that they have inhibitory effects on the actions of IGF-I (Baxter, 2000; Grimberg and Cohen, 2000). For example, with regard to IGFBP-3, maximal IGFBP-3 mRNA expression was seen in corpora lutea undergoing luteolysis in rats (Erickson et al., 1993). In addition, $\mathrm{PGF}_{2 \alpha}$ stimulated, whereas $\mathrm{PGE}_{2}$ inhibited, IGFBP-3 (protein) production by luteinizing pig granulosa cells in culture (Grimes et al., 1993). Furthermore, the present study has shown that the IGFBP-3 protein content was increased in pig corpora lutea after $\mathrm{PGF}_{2 \alpha}$ treatment in vivo (Nicholson et al., 1999). Finally, some recent data in bovine corpora lutea further indicate the inhibitory roles of IGFBP-2 and -3 on IGF-I binding to luteal (IGF-IR) receptors (Brown and Braden, 2001). Taken together, these results indicate that IGFBPS (in particular IGFBP-3) play an inhibitory role in regulating the action of IGF-I in the corpora lutea. The present study sought to examine the role of endogenous IGFBPs in the luteal IGF response mechanism by using the IGF-I analogue, long $R_{3}$-IGF-I, which binds to IGFBPs with lower affinity than does IGF-I (Baxter, 2000). As long $R_{3}$-IGF-I binds to IGF-IR, but minimally to IGFBPs (compared with IGF-I), a greater steroidogenic response to this analogue was expected compared with IGF-I. The results show that progesterone secretion by luteal cells is increased by both long $\mathrm{R}_{3}$ IGF-I and IGF-I to the same degree, indicating that endogenous IGFBPs are not acting as inhibitors of IGF-I actions on pig luteal cells in this cell culture system. Nevertheless, in some related in vitro studies it has been shown that exogenous IGFBP-3 does inhibit the steroidogenic responses of pig luteal cells to exogenous IGF-I, and that an antibody to IGFBP-3 given alone is stimulatory to luteal progesterone secretion (Z. Ge, W. E. Nicholson, V. Hedgpeth and J. E. Gadsby, unpublished). Taken together, these observations indicate that IGFBP-3 can have inhibitory actions on the interactions of IGF-I with its receptors in pig corpora lutea, although the role that the increased IGFBP-3 on days 4-7 (Ge et al., 1998; Z. Ge, W. E. Nicholson, V. Hedgpeth and J. E. Gadsby, unpublished) may play in modulating the action of IGF-I in developing corpora lutea in pigs is unclear.

The fourth objective of the present study was to explore the signal transduction pathway of the steroidogenic actions of IGF-I in pig corpora lutea. This study examined the effects of inhibitors of Pl-3-kinase (Wortmannin and LY 294002) and MAP-kinase (PD 98059) pathways in pig luteal cells, on IGF-I stimulated progesterone secretion. The data presented show that Wortmannin and LY 294002 both significantly inhibit the stimulatory actions of IGF-I on pig luteal cell steroidogenesis, whereas PD 98059 was without effect, strongly indicating the involvement of the PI-3-kinase pathway in mediating the steroidogenic actions of IGF-I in pig corpora lutea. Although there are few, if any, reports of studies on the pathways of the steroidogenic actions of IGF-I in pig ovaries, there is evidence that PI-3-kinase and protein kinase B (or Akt) are involved in mediating the cell survival pathway in pig granulosa cells (Westfall et al., 2000).

In summary, the present study has shown that IGF-I agonists stimulate luteal progesterone production in vitro on days 4 and 7 , but not on days 10-16 of the oestrous cycle, demonstrating the functional competence of IGF-IR and the signal transduction pathway during the early luteal phase. This was confirmed by in vivo 
studies conducted on day 7 . In addition, this study has shown that large luteal cells are the primary target for the steroidogenic actions of IGF-I. The data also indicate that endogenous IGF-I is probably too low to activate steroidogenesis, and that endogenous IGFBPs do not appear to inhibit the action of IGF-I in vitro. Finally, this study demonstrated that IGF-I acts to promote steroidogenesis via the PI-3-kinase pathway. Future studies will be directed towards a more detailed examination of the IGF-I signal transduction pathways and mediators of increased luteal steroidogenic activity, to determine the mechanism by which luteal IGF-I sensitivity changes during the oestrous cycle in pigs.

The authors thank the NCSU Swine Education and Research facility for the supply of research animals and for the use of animal holding and surgical facilities. The authors also wish to acknowledge B. Flowers (Animal Science) for his help with surgeries and J. Davis (University of Nebraska) for his advice in planning the inhibitor studies. This work was supported by USDA NRICGP 98-35203-6283 and the State of North Carolina, USA.

\section{References}

Amselgruber W, Sinowatz F, Schams D and Skottner A (1994) Immunohistochemical aspects of insulin-like growth factors I and II in the bovine corpus luteum Journal of Reproduction and Fertility 101 445-451

Anderson LL and Melampy RM (1968) Hypophysial and uterine influences on pig luteal function. In Reproduction in the Female Mammal pp 285316 Eds GE Lamming and EC Amoroso. Butterworths, London

Apa R, Di Simone N, Ronsisvalle E, Miceli F, de Feo D, Caruso AD, Lanzone A and Mancuso S (1996) Insulin-like growth factor (IGF)-I and IGF-II stimulate progesterone production by human luteal cells: role of IGF-I as mediator of growth hormone action Fertility and Sterility $\mathbf{6 6}$ 235-239

Baxter RC (2000) Insulin-like growth factor (IGF)-binding proteins: interactions with IGFs and intrinsic bioactivities American Journal of Physiology 278 E967-E976

Brown TA and Braden TD (2001) Expression of insulin-like growth factor binding protein (IGFBP)-3, and the effects of IGFBP-2 and -3 in the bovine corpus luteum Domestic Animal Endocrinology 20 203-216

Chen D, Fong HW and Davis JS (2001) Induction of C-fos and c-jun messenger ribonucleic acid expression by prostaglandin $\mathrm{F}_{2 \alpha}$ is mediated by a protein kinase $\mathrm{C}$-dependent extracellular signal-regulated kinase mitogen-activated protein kinase pathway in bovine luteal cells Endocrinology 142 887-895

Constantino CX, Keyes PL and Kostyo JL (1991) Insulin-like growth factor-I stimulates steroidogenesis in rabbit luteal cells Endocrinology $\mathbf{1 2 8} 1702$ 1708

Einspanier R, Miyamoto A, Schams D, Muller M and Brem G (1990) Tissue concentration, mRNA expression and stimulation of IGF-I in luteal tissue during the oestrous cycle and pregnancy of cows Journal of Reproduction and Fertility $90439-445$

Erickson GF, Nakatini A, Ling N and Shimasaki S (1993) Insulin-like growth factor binding protein-3 gene expression is restricted to involuting corpora lutea in rat ovaries Endocrinology 133 1147-1157

Fraser HM, Lunn SF, Kim H and Erickson GF (1998) Insulin-like growth factor-binding protein-3 mRNA in endothelial cells of the primate corpus luteum Human Reproduction 13 2180-2185

Fraser HM, Lunn SF, Kim H, Duncan WC, Rodger FE, Illingworth PJ and Erickson GF (2000) Changes in insulin-like growth factor-binding protein-3 messenger ribonucleic acid in endothelial cells of the human corpus luteum: a possible role in luteal development and rescue Journal of Clinical Endocrinology and Metabolism 85 1672-1677
Gadsby JE and Earnest KL (1994) Prostaglandin $F_{2 \alpha}$ stimulates progesterone secretion by porcine luteal cells in vitro throughout the estrous cycle Prostaglandins 48 109-125

Gadsby JE, Balapure AK, Britt JH and Fitz TA (1990) PGF $_{2 \alpha}$ 'receptors' on enzyme-dissociated pig luteal cells throughout the estrous cycle Endocrinology 126 787-795

Gadsby JE, Smith CA and Almond GW (1991) Acute stimulatory effects of prostaglandin $F_{2 \alpha}$ on serum progesterone concentrations in pregnant and pseudopregnant pigs Prostaglandins 41 419-432

Gadsby JE, Lovdal JA, Samaras S, Barber J and Hammond JM (1996) Expression of messenger ribonucleic acids for insulin-like growth factor I and insulin-like growth factor binding proteins in porcine corpora lutea Biology of Reproduction $\mathbf{5 4}$ 339-346

Ge Z, Nicholson WE, Farin CE and Gadsby JE (1998) Protein concentrations of IGF-I, IGFBP's 2-5 and IGF-type I receptor in porcine corpora lutea Biology of Reproduction 58 Supplement 1218 (Abstract 468)

Ge Z, Nicholson WE, Plotner DM, Farin CE and Gadsby JE (2000a) Expression of the messenger ribonucleic acid and protein for insulin-like growth factor I receptor in porcine corpora lutea Journal of Reproduction and Fertility 120 109-114

Ge Z, Miller E, Farin C, Hedgpeth V and Gadsby JE (2000b) In situ hybridization analysis of IGFBPs-3, -7 and -8 mRNAs in porcine corpora lutea Biology of Reproduction 62 Supplement 1143 (Abstract 96)

Giudice LC (2001) Insulin-like growth factor family in graafian follicle development and function Journal of the Society for Gynecological Investigation 8 S26-S29

Grimberg A and Cohen P (2000) Role of insulin-like growth factors and their binding proteins in growth control and carcinogenesis Journal of Cellular Physiology 183 1-9

Grimes RW, Samaras SE and Hammond JM (1993) Divergent actions of prostaglandins- $E_{2}$ and $-F_{2 \alpha}$ on the regulation of insulin-like growth factor-binding protein-3 in luteinized granulosa cells Endocrinology $\mathbf{1 3 2}$ 1414-1416

Hammond JM, Samaras SE, Grimes R, Leighton J, Barber J, Canning SF and Guthrie HD (1993) The role of insulin-like growth factors and epidermal growth factor-related peptides in intraovarian regulation in the pig ovary Journal of Reproduction and Fertility Supplement 48 $117-125$

Hernandez ER, Hurwitz A, Vera A, Pellicer A, Adashi EY, LeRoith D and Roberts CT, Jr (1992) Expression of the genes encoding the insulin-like growth factors and their receptors in the human ovary Journal of Clinical Endocrinology and Metabolism 74 419-425

Huang CJ, Li Y, Stromer H and Anderson LL (1992) Synergistic effects of insulin-like growth factor I and gonadotrophins on relaxin and progesterone secretion by ageing corpora lutea of pigs Journal of Reproduction and Fertility 96 415-425

Juengel JL, Nett TM, Anthony RV and Niswender GD (1997) Effects of luteotropic and luteolytic hormones on expression of mRNA encoding insulin-like growth factor-I and growth hormone receptor in the ovine corpus luteum Journal of Reproduction and Fertility $\mathbf{1 1 0}$ 291-298

Khan-Dawood FS, Gargiulo AR and Dawood MY (1994) In vitro microdialysis of the ovine corpus luteum of pregnancy: effects of insulin-like growth factor on progesterone secretion Biology of Reproduction $\mathbf{5 1}$ 1299-1306

McArdle CA and Holtorf AP (1989) Oxytocin and progesterone release from bovine corpus luteal cells in culture: effects of insulin-like growth factor I, insulin, and prostaglandins Endocrinology 124 1278-1286

Mondschein JS, Canning SF, Miller DQ and Hammond JM (1989) Insulinlike growth factors (IGFs) as autocrine/paracrine regulators of granulosa cell differentiation and growth: studies with a neutralizing monoclonal antibody to IGF-I Biology of Reproduction 40 79-85

Monget P and Bondy C (2000) Importance of the IGF system in early folliculogenesis Molecular and Cellular Endocrinology 163 89-93

Nicholson WE, Plotner DM, Farin CE and Gadsby JE (1999) Insulinlike growth factor-I, insulin-like growth factor-I receptor and insulinlike growth factor binding protein-3 messenger ribonucleic acids and protein in corpora lutea from prostaglandin $\mathrm{F}_{2 \alpha}$-treated gilts Biology of Reproduction 61 1527-1534 
Niswender GD, Juengel JL, Silva PJ, Rollyson MK and McIntush EW (2000) Mechanisms controlling the function and life span of the corpus luteum Physiological Reviews 80 1-29

Oxenreider SL, McClure RC and Day BN (1965) Arteries and veins of the internal genitalia of female swine Journal of Reproduction and Fertility 9 19-27

Parmer TG, Roberts CT, Jr, LeRoith D, Adashi EY, Khan I, Solan N, Nelson S, Zilberstein M and Gibori G (1991) Expression, action and steroidal regulation of insulin-like growth factor I (IGF-I) and IGF-I receptor in the rat corpus luteum: their differential role in the two cell populations forming the corpus luteum Endocrinology 129 2924-2932

Perks CM, Denning-Kendall PA, Gilmour RS and Wathes DC (1995) Localization of messenger ribonucleic acids for insulin-like growth factor I (IGF-I), IGF-II and the type 1 IGF receptor in the ovine ovary throughout the estrous cycle Endocrinology 136 5266-5273

Perks CM, Peters AR and Wathes DC (1999) Follicular and luteal expression of insulin-like growth factors I and II and the type 1 IGF receptor in the bovine ovary Endocrinology 136 5266-5273

Richards RG, Gadsby JE and Almond GW (1994) Differential effects of luteinizing hormone and prostaglandin $\mathrm{E}_{2}$ on progesterone secretion by small and large luteal cells Journal of Reproduction and Fertility $\mathbf{1 0 2}$ 27-34

Rohlik QT, Adams D, Kull FC, Jr and Jacobs S (1987) An antibody to the receptor for insulin-like growth factor I inhibits the growth of MCF-7 cells in tissue culture Biochemical and Biophysical Research Communications 149 276-281
Sauerwein H, Miyamoto A, Gunther J, Meyer HHD and Schams D (1992) Binding and action of insulin-like growth factors and insulin in bovine luteal tissue during the oestrous cycle Journal of Reproduction and Fertility 96 103-115

Talavera F and Menon KMJ (1991) Studies on rat luteal cell response to insulin-like growth factor (IGF-I): identification of specific cell membrane receptor for IGF-I in the luteinized rat ovary Endocrinology 1291340 1346

Valentinis B and Baserga R (2001) IGF-I receptor signalling in transformation and differentiation Journal of Clinical Pathology: Molecular Pathology $\mathbf{5 4}$ 133-137

Wathes DC, Perks CM, Davis AJ and Denning-Kendall PA (1995) Regulation of insulin-like growth factor I and progesterone synthesis by insulin and growth hormone in the ovine ovary Biology of Reproduction 53 882-889

Westfall SD, Hendry IR, Obholz KL, Rueda BR and Davis JS (2000) Putative role of the phosphatidylinositol 3-kinase-Akt signaling pathway in the survival of granulosa cells Endocrine 12 315-321

Yuan W and Lucy MC (1996) Effects of growth hormone, prolactin, insulinlike growth factors and gonadotropins on progesterone secretion by porcine luteal cells Journal of Animal Science 74 866-872

Received 27 June 2002.

First decision 2 September 2002.

Revised manuscript received 27 September 2002.

Accepted 24 October 2002. 